\title{
INTRODUCING AUTOMATIC ULTRASONIC INSPECTION TECHNOLOGY TO WELDED RAILS ON A FLEXIBLE FLOATING RAILWAY BRIDGE
}

\author{
HYUNG SUK MUN \& SUNG IL SEO \\ Korea Railroad Research Institute, Korea
}

\begin{abstract}
A floating bridge was developed mainly for the use of motor vehicles. In recent years, studies on the application of such bridge types for railway vehicles are being carried out. Railways respond sensitively to flexible structures, such as floating bridges, and the welded joints of rails are vulnerable to continuous deformation. The focus of this study is regarding the automatic ultrasonic detection device for rails. More specifically, this device moves between rails automatically and inspects cracks in the welded joints connecting adjacent rails. When the device is not inspecting the welded joints it remains parked between rails. This study intends to introduce the design drawing, management and operation methods of the automatic ultrasonic detection and test device for rails. This technology can be applicable to inaccessible areas efficiently.
\end{abstract}

Keywords: ultrasonic, inspection, bridge, floating, welded rail.

\section{INTRODUCTION: FLOATING BRIDGE EXISTING IN THE WORLD}

The status of large and small floating bridges constructed previously is as shown in the Table 1. The existing floating bridges were constructed at varying water depths from $500 \mathrm{~m}$ at the deepest to $61 \mathrm{~m}$. We can see that the largest number of floating bridges have been constructed in Seattle, the United States.

\section{DYNAMIC DISPLACEMENT OF FLOATING BRIDGE}

Many floating bridges are being operated in Seattle, the United States. Recently, a floating bridge enabling the operation of the railway vehicles is under construction as shown in Fig. 1.

Table 2 shows the degree of longitudinal movement and vertical rotation of floating bridge; suspension bridge and cable stay bridge where railway tracks are installed. As such displacements are significantly larger than the normal displacements of railway track constructed on the ground, safety measures according to those are required.

\section{WELDED RAIL ON FLOATING BRIDGE}

The rail is installed on a floating bridge where the railroad crosses. As mentioned earlier, there are two major safety issues in the floating bridge with large displacements including derailment and a crack on the welded rail joints. While the derailment expected according to the displacement of the track can be prevented after analyzing the speed of railway vehicles and the movement of the track, the crack and fracture on the welded rail joints expected to occur through a series of deformations can be prevented through the real-time safety report system. Securing the safety of the welded rail track connection installed on a floating bridge, which is highly vulnerable to displacements compared to the normal track fixed on the ground, is very important for the operation of a floating railway bridge. 
Table 1: Major floating bridges around the world [1]. (Source: Translated from the guideline for design of floating brides Japan society of civil engineers, $p .8$, March 2006.)

\begin{tabular}{|c|c|c|c|c|c|c|}
\hline No. & Year & Name & Location & $\begin{array}{l}\text { Deepest } \\
(\mathrm{m})\end{array}$ & $\begin{array}{l}\text { Length } \\
(\mathrm{m})\end{array}$ & $\begin{array}{c}\text { Pontoon } \\
\text { dimensions }(\mathrm{m})\end{array}$ \\
\hline 1 & 1912 & Galata & $\begin{array}{l}\text { Istanbul, Turkey } \\
\text { (River mouth) }\end{array}$ & 41 & 466 & $25 \times 9 \times 3.7$ \\
\hline 2 & 1940 & $\begin{array}{l}\text { Lacey V } \\
\text { Murrow }\end{array}$ & $\begin{array}{l}\text { Washington } \\
\text { State, USA } \\
\text { (Lake) }\end{array}$ & 7 & 2,018 & $107 \times 18 \times 4.4$ \\
\hline 3 & 1943 & Hobart & $\begin{array}{c}\text { Tasmania, } \\
\text { Australia (River } \\
\text { mouth) }\end{array}$ & 31 & 965 & $40 \times 11 \times 3.7$ \\
\hline 4 & 1957 & Kelowna & $\begin{array}{c}\text { British Columbia, } \\
\text { Canada (Lake) }\end{array}$ & 49 & 640 & $61 \times 15 \times 4.6$ \\
\hline 5 & 1961 & $\begin{array}{l}\text { Hood Canal } \\
\text { Old (east side) }\end{array}$ & $\begin{array}{l}\text { Washington } \\
\text { State, USA } \\
\text { (Lake) }\end{array}$ & 104 & 1,972 & $110 \times 15 \times 4.4$ \\
\hline 6 & 1963 & $\begin{array}{l}\text { Evergreen } \\
\text { point }\end{array}$ & $\begin{array}{l}\text { Washington } \\
\text { State, USA } \\
\text { (Lake) }\end{array}$ & 61 & 2,310 & $110 \times 18 \times 4.5$ \\
\hline 7 & 1983 & $\begin{array}{l}\text { Hood Canal } \\
\text { new } \\
\text { (westside) }\end{array}$ & $\begin{array}{l}\text { Washington } \\
\text { State, USA } \\
\text { (Lake) }\end{array}$ & 104 & 1,972 & $110 \times 18 \times 5.5$ \\
\hline 8 & 1989 & $\begin{array}{l}\text { Third Lake } \\
\text { Washington }\end{array}$ & $\begin{array}{l}\text { Washington } \\
\text { State, USA } \\
\text { (Lake) }\end{array}$ & 61 & 1,771 & $108 \times 23 \times 5.0$ \\
\hline 9 & 1992 & Bergsoysund & $\begin{array}{l}\text { Kristiansund, } \\
\text { Norway (Fjord) }\end{array}$ & 300 & 934 & $34 \times 20 \times 6.0$ \\
\hline 10 & 1994 & Nordhordland & $\begin{array}{l}\text { Bergen, Norway } \\
\text { (Fjord) }\end{array}$ & 500 & 1,246 & $42 \times 12.5 \times 6.8$ \\
\hline 11 & 1996 & $\begin{array}{c}\text { West India } \\
\text { Quay Foot } \\
\text { Bridge }\end{array}$ & $\begin{array}{l}\text { London, England } \\
\text { (River mouth) }\end{array}$ & & 94 & $\Phi 2.8 \times 10$ \\
\hline 12 & 1996 & $\begin{array}{c}\text { Nagoya Fish } \\
\text { Port } \\
\text { Terminal }\end{array}$ & $\begin{array}{l}\text { Nagoya, Saga, } \\
\text { Japan (Inner } \\
\text { Harbor) }\end{array}$ & 10 & 110 & $110 \times 15 \times 3.0$ \\
\hline 13 & 1998 & $\begin{array}{l}\text { Admiral } \\
\text { Clarey }\end{array}$ & $\begin{array}{l}\text { Hawaii, USA } \\
\text { (Inner Harbor) }\end{array}$ & 15 & 310 & $93 \times 15 \times 5.1$ \\
\hline 14 & 2000 & Kujira & $\begin{array}{l}\text { Nishino Omote, } \\
\text { Kagoshima } \\
\text { (Lake) }\end{array}$ & & 180 & \\
\hline 15 & 2000 & $\begin{array}{l}\text { Mumai } \\
\text { Oohashi }\end{array}$ & $\begin{array}{l}\text { Osaka (Inner } \\
\text { Harbor) }\end{array}$ & 10 & 410 & $58 \times 58 \times 8.0$ \\
\hline
\end{tabular}






Figure 1: Railway floating bridge in Seattle [2].

Table 2: Comparison results of maximum displacements of flexible railway bridges.

\begin{tabular}{|c|c|c|c|}
\hline $\begin{array}{c}\text { Type of } \\
\text { bridges }\end{array}$ & $\begin{array}{c}\text { Floating railway bridge } \\
{[3]}\end{array}$ & $\begin{array}{c}\text { Suspension railway bridge } \\
\text { Cable stay railway bridge }\end{array}$ \\
\hline $\begin{array}{c}\text { Name of } \\
\text { bridges }\end{array}$ & $\begin{array}{c}\text { I-90 Bridge } \\
\text { (modeled) Seattle }\end{array}$ & $\begin{array}{c}\text { Tagus River Bridge } \\
\text { Lisbon, Portugal }\end{array}$ & $\begin{array}{c}\text { SkyTrain Bridge } \\
\text { Vancouver, BC }\end{array}$ \\
\hline $\begin{array}{c}\text { Longitudinal } \\
\text { movement }\end{array}$ & $622.3 \mathrm{~mm}$ & $1,524 \mathrm{~mm}$ & $332.74 \mathrm{~mm}$ \\
\hline $\begin{array}{c}\text { Vertical } \\
\text { rotation }\end{array}$ & 2.2 degrees(downward) & $+/-3.43$ degrees & $+/-0.75$ degrees \\
\hline
\end{tabular}



Figure 2: Process rail welding. 


\section{AUTOMATIC ULTRASONIC INSPECTION DEVICE AN METHOD}

Generally, a long rail is produced through the rolling mill and it is cut in a fixed size within $20-25 \mathrm{~m}$, and the track is installed using such produced rails to enable the operation of railway vehicles. A number of rails are connected in the way that a rail produced in a fixed length is welded with a neighboring rail, installing the track with continuous welded rails that enables the operation of railway vehicles. Once railway vehicles run on the installed track repeatedly, cracks will occur on the welded rail joints connecting neighboring rails due to fatigue.

The welded rail joints which connect the neighboring rails should be inspected frequently and ensure safe operation of railway vehicles through the repair work once a crack is found. The inspection of welded rail joints between neighboring rails for the existence of a crack is carried out at night when the railway vehicles are not operated. In the previous method to inspect the welded rail joints between neighboring rails, an inspector gets on the vehicle operated on the track and inspects the occurrence of a crack using a probe installed on the vehicle, while moving to the welded rail joints between neighboring rails.

Since the inspection of welded rail joints between neighboring rails for the existence of a crack is carried out while running on the track, there is an inconvenience that the vehicle that is inspected should be warehoused on the railway depot during the daytime when railway vehicles are operated, so that it does not obstruct the operation of railway vehicles. Another inconvenience is that the existence of a crack on the welded rail joints between neighboring rails is inspected while running on the track, which requires a lot of manpower and a long time.

\section{SUMMARY OF TECHNOLOGY}

This invention is about the automatic ultrasonic inspection vehicle for rails that can travel automatically between rails, inspecting the welded rail joints between neighboring rails for the existence of a crack, or remain parked between rails when the welded rail joints are not inspected.

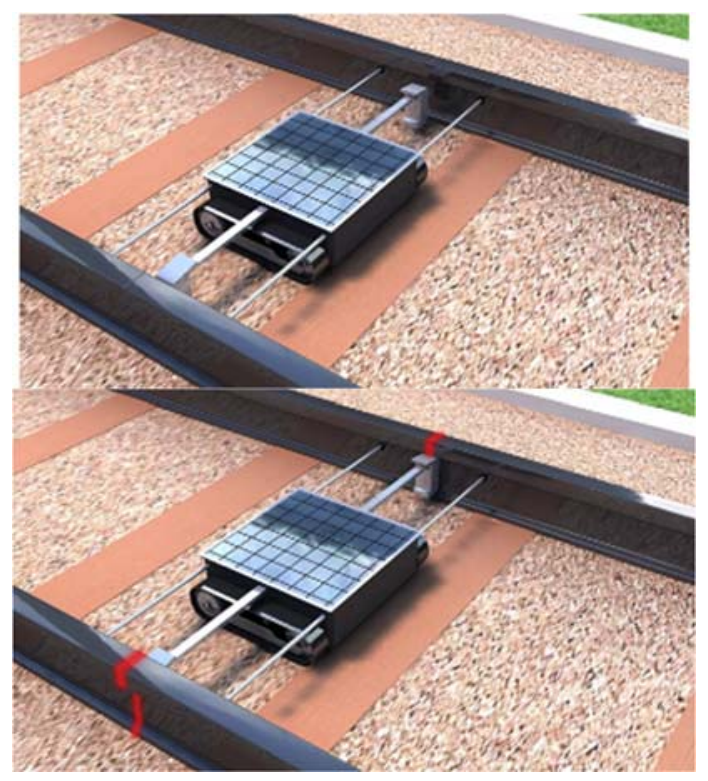

Figure 3: Detection vehicle of welded joint rail by using ultrasonic. 


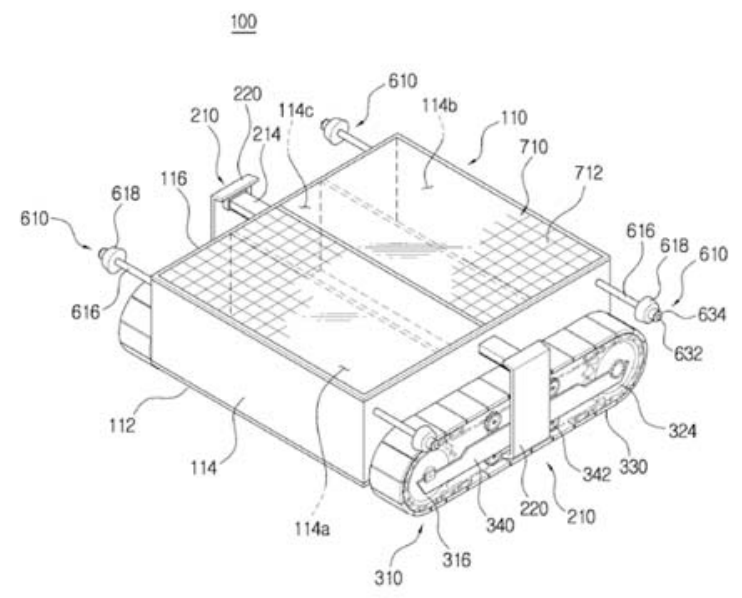

Figure 4: The drawing of automatic ultrasonic inspection vehicle (iso view).
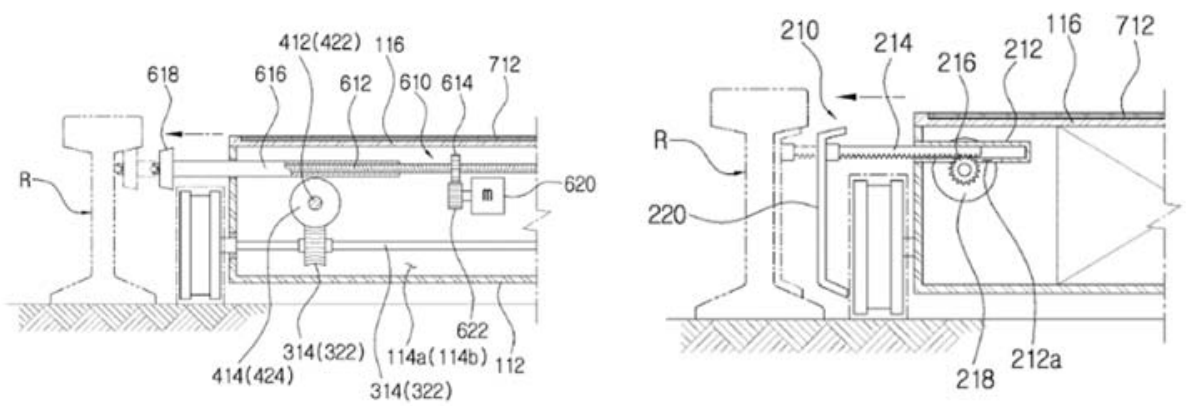

Figure 5: The drawing of automatic ultrasonic inspection vehicle (side view).

In order to achieve the above-mentioned purposes, this invention features the body, wheels installed on both sides of the body, the operation unit installed on the body for operating the wheels, and the driveline system which transmits power to the operation unit.

\section{IMPROVEMENT OF DESIGN}

The design of this technology was improved as follows for smooth operation on the ballast railway track. The design was modified in order to enable separate management of ballast in the traveling direction of the automatic ultrasonic inspection vehicle.

\section{CONCLUSION}

1. In this design, the automatic ultrasonic inspection vehicle travels automatically between the rails installed on the track, inspecting the welded rail joints between neighboring rails for the existence of a crack, requiring no additional inspection manpower to inspect the existence of a crack on the welded rail joints between neighboring rails and saving costs including the labor costs. 


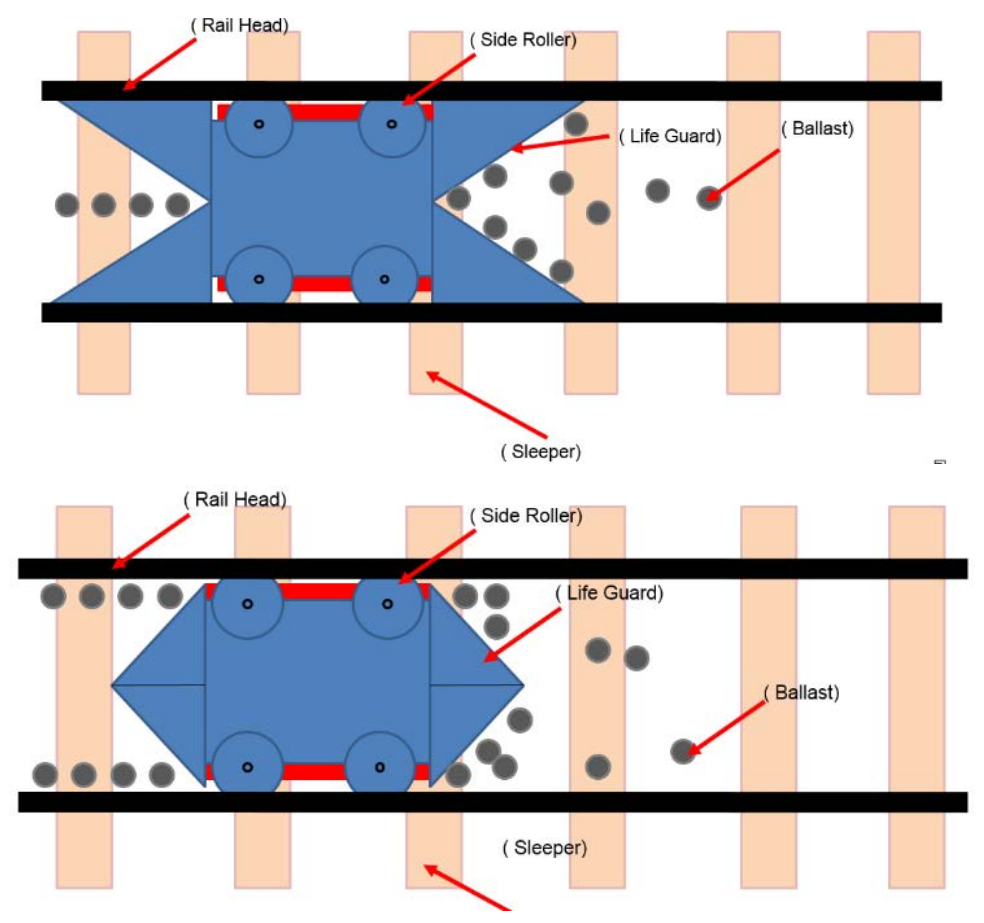

Figure 6: Operational design of automatic ultrasonic inspection vehicle with ballast in track.

2. While the welded rail joints between neighboring rails for a crack are not under inspection, the automatic ultrasonic inspection vehicle remains parked between rails installed on the track, so that it does not affect the operation of railway vehicles on the track.

3. The supporting part that supports the inner side of the rail is installed on both sides and on front and rear of the body, enabling the automatic ultrasonic inspection vehicle to carry out the inspection of welded rail joints between neighboring rails for a crack while operating safely without going off the rail.

4. The detection unit can be drawn from the body so that it can place itself on the welded rail joints, and the fixed ultrasonic detection unit is drawn, checking for the existence of a crack, and then returns to its original position, enabling the automatic ultrasonic inspection vehicle to travel safely without any interruption.

5. The solar cell installed on the top generates power through self-charging, enabling the operation of the automatic ultrasonic inspection vehicle.

6. The design was improved in the way to manage the ballast in the track safely, improving its utilization.

\section{REFERENCES}

[1] Saleh, A.H., Mega floating concrete bridges. Master's thesis, TU Delft, The Netherlands, 23 Aug. 2010. 
[2] KPFF Consulting Engineers, Homer Hadley (Interstate 90) Floating Bridge Test Program for Light Rail Transit Draft Test Report, KPFF project number 104577.20, 14 Nov. 2005

[3] Havens, E.B., Light Rail, Streetcar Projects Advancing Nationwide Part 1. http://www.trolleyville.com/tv/times/sept2015/headline09.html. Accessed on: $20 \mathrm{Jul}$. 2017.

[4] Mun, H.-S., Kwon, T.-S. \& Seo, S.-I., An automatic supersonic detection device for railroad rail. Korea Patent 10-1196826-0000, 2012. 